\title{
KONSEP EKONOMI PADA MASA IBNU KHALDUN DAN ALGHAZALI
}

Oleh:

abdul azis alfaruqi (90100118046)

\section{A. PEMIKIRAN IBNU KHALDUN TENTANG EKONOMI}

Pemikiran Ekonomi Ibnu Khaldun Salah satu karya fenomenal Ibnu Khaldun adalah Kitab Al-Muqaddimah, yang selesai penulisannya pada Nopember 1377. Sebuah kitab yang sangat menakjubkan, karena isinya mencakup berbagai aspek ilmu dan kehidupan manusia pada ketika itu. Al-Muqaddimah secara harfiah bararti 'pembukaan' atau 'introduksi' dan merupakan jilid pembuka dari tujuh jilid tulisan sejarah. Al-Muqaddimah mencoba untuk menjelaskan prinsip-prinsip yang menentukan kebangkitan dan keruntuhan dinasti yang berkuasa (daulah) dan peradaban ('umran). Tetapi bukan hanya itu saja yang dibahas. Al-Muqaddimah juga berisi diskusi ekonomi, sosiologi dan ilmu politik, yang merupakan kontribusi orisinil Ibnu Khaldun untuk cabang-cabang ilmu tersebut. Ibnu Khaldun juga layak mendapatkan penghargaan atas formula dan ekspresinya yang lebih jelas dan elegan dari hasil karya pendahulunya atau hasil karya ilmuwan yang sejaman dengannya. Melahirkan karya Al-Muqaddimah menjadikan Ibnu Khaldun sebagai seorang genius polymath (jenius dalam berbagai bakat) dan seorang renaissance man yang menguasai banyak bidang ilmu. Di dalam kitab ini, Ibnu Khaldun membincangkan berbagai topik seperti sejarah, geografi, matematik, agama, sistem kerajaan, sistem ekonomi, sistem pendidikan dan lain-lain.

Dalam Masalah Ekonomi Islam Ibn Khaldun membahas aneka ragam masalah ekonomi yang luas, termasuk ajaran tentang tata nilai, pembagian kerja, sistem harga, hukum penawaran dan permintaan, konsumsi dan produksi, uang, pembentukan modal, pertumbuhan penduduk, makro ekonomi dari pajak dan pengeluaran publik, daur perdagangan, pertanian, indusrtri dan perdagangan, hak milik dan kemakmuran, dan sebagainya. Ia juga membahas berbagai tahapan yang dilewati masyarakat dalam perkembangan ekonominya. Kita juga menemukan paham dasar yang menjelma dalam kurva penawaran tenaga kerja yang kemiringannya berjenjang mundur. 


\section{B. PEMIKIRAN IMAM GHAZALI TENTANG EKONOMI}

Imam Ghazali dikenal memiliki pemikiran yang luas dalam berbagai bidang, tidak terkecuali tentang ekonomi. Pemikirannya dapat ditemukan di beberapa karya beliau diantaranya Ihya' Ulum al-Din, Al-Mustafa, Mizan al-Amal, Al Tibr al Masbuk fi Nasihat al Muluk dan lain sebagainya. Pemikiran Imam Ghazali tentang ekonomi antara lain meliputi uang, perdagangan, pembagian tenaga kerja, perilaku konsumsi dan organisasi masyarakat dalam perekonomian. Disamping itu menurut Imam Ghazali kebutuhan dasar termasuk kebutuhan rumah tangga yang diperlukan, fornitur, peralatan pernikahan, alat-alat untuk membesarkan keluarga dan beberapa aset lainnya. Pembahasan ekonomi Imam Ghazali mencakup aspek yang sangat luas, namun secara garis besar dapat dikelompokkan menjadi : pertukaran dan evolusi pasar, produksi, baeter dan evolusi uang, serta peranan negara dan keuangan publik. Imam Ghazali juga memperkaya ekonomi Islam dengan topik pembagian kerja dan teori evolusi uang. Imam ghazali juga mengecam penimbunan uang di bawah lantai atau bantal, karena uang diciptakan untuk memfasilitasi perdagangan, sedangkan penimbunan uang di bawah lantai atau bantal akan mengeluarkan uang dari proses ini. Sebagai seorang sufi, Imam Ghazali banyak memberikan kontribusi yang berarti dalam memberikan pandangan-pandangan yang bersifat spiritual dan moral dalam ilmu ekonomi.

Perhatian al-Gazali terhadap kehidupan masyarakat tidak terfokus pada satu bidang tertentu, tetapi meliputi aspek kehidupan manusia. Ia melakukan studi keislaman secara luas untuk mempertahankan ajaran agama Islam. Oleh karena itu, kita tidak menemukan sebuah karya tulisnya yang khusus membahas ekonomi Islam. Perhatiannya di bidang ekonomi itu terkandung dalam berbagai studi fiqihnya, karena ekonomi Islam, pada hakikatnya merupakan bagian yang tak terpisahkan dari fiqih Islam. 


\section{DAFTAR PUSTAKA}

Huda, C. (2013). Pemikiran Ekonomi Bapak Ekonomi Islam; Ibnu Khaldun. Economica: Jurnal Ekonomi Islam, 4(1), 103-124.

Ulum, B. (2016). Kontribusi Ibnu Khaldun Terhadap Perkembangan Ekonomi Islam. Iqtishodia: Jurnal Ekonomi Syariah, 1(2), 17-32.

Faizal, M. F. (2015). Studi Pemikiran Imam Al-Ghazali Tentang Ekonomi Islam. Islamic Banking: Jurnal Pemikiran dan Pengembangan Perbankan Syariah, 1(1), 49-58.

Fahlefi, R. (2018). Pemikiran Ekonomi al-Ghazali. JURIS (Jurnal Ilmiah Syariah), 11(1), 22-32.

Sirajuddin. (2016). Konsep Pemikiran Ekonomi Al-Ghazali. 3(1). 47-60 